\title{
31. THE MAGNETOSTRATIGRAPHY OF OCEAN DRILLING PROGRAM LEG 105 SEDIMENTS 1
}

\author{
Brad M. Clement, ${ }^{2}$ Frank J. Hall, ${ }^{3}$ and Richard D. Jarrard ${ }^{4}$
}

\begin{abstract}
During Leg 105 of the Ocean Drilling Program, a series of 11 holes was drilled at three sites along a north-south transect in Baffin Bay and the Labrador Sea. Intermittent recovery and drilling disturbance, resulting in part from the harsh weather conditions encountered, hampered magnetostratigraphic study. In particular, incomplete recovery of undisturbed sediment and sparse biostratigraphic control make it difficult to correlate the polarity zones observed in sediments recovered at Site 645 in Baffin Bay with the geomagnetic polarity time scale. However, the undisturbed PliocenePleistocene sediments recovered using the advanced piston corer (APC) at Sites 646 and 647 yield polarity sequences that are readily correlated with the time scale. Deeper sequences cored using the extended core barrel (XCB) corer at Site 646 provide a coarse polarity sequence that, in conjunction with the available biostratigraphic data, may be correlated tentatively with late Miocene reversal sequences. The polarity record obtained from a relatively undisturbed upper Eocene sequence recovered from Hole 647A using the rotary core barrel (RCB) is correlated with Chronozones C19 through $\mathrm{C} 18$.
\end{abstract}

\section{INTRODUCTION}

During ODP Leg 105, three sites were drilled in the Labrador Sea and Baffin Bay to study the paleoceanographic and tectonic evolution of these basins (Srivastava, Arthur, et al., 1987). Today, the Labrador Sea and Baffin Bay form the western branch of the North Atlantic Ocean, and before the opening of the Greenland and Norwegian seas in the Eocene, they served as the primary connection between the Arctic and Atlantic oceans (Gradstein and Srivastava, 1980). The tectonic development of this passageway had an important effect on patterns of watermass exchange between the Atlantic middle latitudes and the polar regions. One objective of Leg 105 was to study the tectonic evolution and the history of circulation through these basins.

Despite extensive marine geophysical surveys through this area and the numerous oil exploratory wells that have been drilled on the continental margins, the timing of the tectonic events that formed Baffin Bay and the Labrador Sea is still not well known. A primary goal of Leg 105 was to establish a chronostratigraphy to constrain the timing and rates of both tectonic and paleoceanographic changes in these high-latitude basins. Here, we report the results of a magnetostratigraphic study of the sediments cored during Leg 105. Sediments at all three sites exhibit both normal- and reverse-polarity magnetizations, which are interpreted as recording geomagnetic polarity reversals. Correlation of the magnetic polarity zones observed in these sediments with the geomagnetic polarity time scale (Berggren et al., 1985) provides a temporal framework for lithostratigraphic and paleoceanographic studies.

\section{METHODS}

Shipboard paleomagnetic measurements included both pass-through and discrete-sample remanence measurements. The pass-through, threeaxis cryogenic magnetometer was used to measure the archive halves of

\footnotetext{
${ }^{1}$ Srivastava, S. P., Arthur, M., Clement, B., et al., 1989. Proc. ODP, Sci. Results, 105: College Station, TX (Ocean Drilling Program).

2 Dept. of Geology, Florida International University, Miami, FL 33199. 02882 .

duate School of Oceanography, Univ. of Rhode Island, Narragansett, RI

${ }^{4}$ Lamont-Doherty Geological Observatory, Columbia Univ., Palisades, NY
}

core sections aboard the JOIDES Resolution. In some instances, a core was too disturbed to warrant measuring using the pass-through cryogenic magnetometer, yet it was still possible to recover discrete samples from undisturbed intervals or biscuits from that core. Discrete samples were recovered by pressing $7-\mathrm{cm}^{3}$ plastic cubes into the working halves of the cored sediment. Using the standard ODP orientation conventions, the positive $Z$ axis is downcore and the $X$ axis is perpendicular to the split face of the working half of the core section. At depths where the sediment was too stiff to sample using the plastic boxes, oriented sections were removed from the core, and minicores were drilled using a drill press and a diamond drill bit. Samples were recovered at intervals ranging from 0.2 to $1.5 \mathrm{~m}$. The high sedimentation-rate material cored during Leg 105 made it possible for us to establish a polarity zonation for these sampling intervals.

Within-core orientation was maintained by orienting the samples with respect to the split face of the core and the vertical axis. The cores were split so that a reference line on the core liner remained in the center of the working half of the core. When APC cores are oriented using the Eastman-Whipstock multishot tool, the reference line on the core liner can be related to geographic north. No between-core orientation can be maintained during rotary coring with either the XCB or the RCB.

The direction and magnitude of the magnetization of discrete samples were measured aboard ship using a Molspin fluxgate spinner magnetometer. Progressive alternating-field (AF) demagnetization studies were conducted by demagnetizing specimens from characteristic lithologies in three orthogonal positions using a Schonstedt, single-axis, AF demagnetizer.

The magnetization of the archive halves of the core sections was measured at 5- to $10-\mathrm{cm}$ intervals using the three-axis, pass-through, cryogenic magnetometer. Archive halves instead of whole cores were measured so that the sediment could be partially demagnetized using the set of three Helmholtz coils that are mounted in line with the cryogenic magnetometer. Measuring the archive halves also allowed us to identify intervals of disturbed sediment before the cores were measured. The pass-through demagnetizer was physically limited to a peak field of $9 \mathrm{mT}$ because of equipment limitations. Up to this peak field, results of demagnetization appear to agree with demagnetization of discrete samples using the single-axis demagnetizer. In general, good agreement was observed between results of the pass-through and discrete samples treated at the same demagnetization level. However, the low AF treatments of the pass-through demagnetizer were not always high enough to remove the overprints completely.

After the cruise, additional samples were taken to obtain increased stratigraphic resolution. The new samples and many of the shipboard samples were measured on shore using cryogenic magnetometers at paleomagnetic laboratories at the Univ. of Rhode Island Graduate School of Oceanography (Sites 645 and 646) and at Lamont-Doherty Geological Observatory (Sites 646 and 647). Additional progressive demagnet- 
ization curves ( $\mathrm{AF}$ and thermal) were run to characterize better the magnetizations of samples from the deeper intervals that appeared to have been subjected to a more complex diagenetic history.

\section{NOMENCLATURE}

Terminology used to describe polarity intervals has become somewhat confused because each of the polarity times scales published recently used different nomenclatures (Ness et al., 1980; Cox, 1982; Berggren et al., 1985; see Tauxe et al., 1987 for a review). These different nomenclatures arose from the need to specify precisely each polarity unit independently of its age (which may be subject to change with further numerical calibration of the reversal sequence) and to correct the anomaly 5Chronozone 9 miscorrelation (Miller et al., 1985; Berggren et al., 1985). Here, we correlate polarity zonations observed in the sediment sequences with the reversal pattern in the marine magnetic anomalies (Heirtzler, 1968; LaBrecque et al., 1977). For this reason, we favor a nomenclature that identifies the polarity intervals in terms of the anomaly sequence and use the nomenclature described by LaBrecque et al. (1983). However, we still refer to the four most recent intervals of dominant polarity by their commonly used names (Brunhes, Matuyama, Gauss, and Gilbert).

\section{RESULTS}

\section{Site 645}

Site 645 was drilled in Baffin Bay $\left(70^{\circ} 27.43^{\prime} \mathrm{N}, 64^{\circ} 39.26^{\prime} \mathrm{W}\right)$ to obtain a sedimentary sequence documenting the tectonic evolution of this small ocean basin and the role it played as a corridor for watermass exchange between the Atlantic and Arctic oceans. Seven holes were drilled at Site 645; the deepest penetrated to 1147 meters below seafloor (mbsf). The recovered sequence is dominated by terrigenous silty clays and muds to sandy silts. The sequence is marked by notably sparse assemblages of planktonic microfossils. Because microfossils were rare, ages were difficult to determine. Most of the available age information is based on benthic foraminifer and dinocyst datums (Srivastava, Arthur, et al., 1987). Although numerous normaland reverse-polarity intervals were observed, the lack of biostratigraphic constraints makes it difficult to correlate the reversal sequence with the geomagnetic polarity time scale.

The sediment recovered from Holes 645B (0-299 mbsf), 645D (266-466 mbsf), and 645E (301-1147 mbsf) provides a composite section that spans the lowermost Miocene to the Holocene. Hole $645 \mathrm{~B}$ was cored using the $\mathrm{XCB}$, and $57 \%$ of the cored interval was recovered. The RCB was used to core both Holes $645 \mathrm{D}$ and $645 \mathrm{E}$, where $58 \%$ and $74 \%$, respectively, of the cored interval was recovered. Because the XCB and RCB were used at this site, no between-core azimuthal orientation was possible; and, in many cases, the coring process mechanically disturbed the sediment to the extent that it could not be sampled for paleomagnetic study. Only results from intervals that did not appear to be disturbed are presented here, although in homogeneous lithologies, it was often difficult to gauge the extent of disturbance. The combination of poor core recovery and intervals of core disturbance results in large gaps in the data, further complicating the correlation of the polarity sequence with the polarity time scale.

The terrigenous sediments cored at Site 645 exhibit straightforward magnetizations. Examples of progressive AF demagnetization are shown in Figure 1 and plotted as vector end-point diagrams (Zijderveld, 1967). Samples yielding both normal- and reverse-polarity magnetizations exhibit characteristic magnetizations defined by a nearly linear decay toward the origin, which is isolated after treatment at 5 to $10 \mathrm{mT}$. Below $900 \mathrm{mbsf}$, all samples yielded normal-polarity magnetizations. Progressive AF de- magnetization of samples from this interval reveals single-component magnetizations, but the notable absence of reversals suggests that this interval may have been completely overprinted.

Results from discrete-sample measurements from Hole 645B are plotted in Figure 2. Because no azimuthal orientation was available, only the inclination record is presented. The steep inclinations $\left(79^{\circ}\right)$ expected at this high-latitude site make it possible to determine its polarity on the basis of the inclination data alone. However, the inclination record is complicated by a great deal of scatter. The results of progressive demagnetization indicate that this scatter is not the result of an incompletely removed overprint, but more likely results from orientation errors induced by drilling disturbance. Also shown in Figure 2 are the polarity log and the preferred correlation of the observed polarity $\log$ with the geomagnetic polarity time scale (Berggren et al., $1985)$. Although the record is hampered by poor recovery and intervals of disturbed sediment, no reverse polarity directions can be seen above 94 mbsf. The occurrence of the dinocyst Multispinula minuita from 0 to 177 mbsf places this interval in the Pleistocene (Srivastava, Arthur, et al., 1987). For this reason, the base of the normal-polarity magnetozone at $94 \mathrm{mbsf}$ is correlated with the Brunhes-Matuyama reversal, and the short normal-polarity zone extending from 115 to at least $126 \mathrm{mbsf}$ is correlated tentatively with the Jaramillo Subchronozone. Below $130 \mathrm{mbsf}$, the inclination record becomes more erratic because of increased sediment disturbance, and it becomes more difficult to assign polarity zonations.

Using the RCB, Hole 645D was cored from 265.7 to 465.8 mbsf; upper Pliocene to lower Pleistocene clayey silts to muddy sandstones were recovered, although recovery of undisturbed sediment was poor, except from 400 to 460 mbsf. The inclination record obtained using both the pass-through cryogenic magnetometer (after treatment at $9 \mathrm{mT}$ ) and discrete-sample measurements (after treatment at $10 \mathrm{mT}$ ) is shown in Figure 3, together with the interpreted polarity, which was based on inclination data. Most measurements of discrete samples (Fig. 3) exhibit a good correlation with the pass-through measurements; the few discrete measurements having shallow inclinations $\left(<30^{\circ}\right)$ do not agree with the pass-through measurements. The occurrence of the benthic foraminifer Cassidulina teretis from 177 to 294 mbsf suggests that this interval is late Pliocene to Holocene in age. This is supported by the occurrence of sinistral-coiling Neoglobogerina pachyderma in this interval. Diatom assemblages in samples from 294 to 512 mbsf suggest that this interval is Pliocene or younger.

Based on the age constraints provided by the biostratigraphic results, the predominantly reverse-polarity interval from 400 to 437 mbsf can be correlated with the Matuyama Chronozone, and the dominantly normal-polarity interval from 437 to 460 mbsf is correlated with the Gauss Chronozone. The short reverse-polarity interval from 446 to 448 mbsf may correlate with either the Kaena or the Mammoth subchronozones, but because of the gaps in the record, it is not possible to correlate this interval with any certainty.

Lowermost Miocene to Pliocene muddy sandstone and silty mudstones were recovered from Hole $645 \mathrm{E}$. Core recovery for the hole averaged $74 \%$; however, much of the material recovered was too disturbed to be sampled for paleomagnetic study. The inclination records obtained from both pass-through and discrete-sample measurements are shown in Figure 4. Generally, good agreement between the two data sets can be seen down to 600 mbsf. Below this depth, the pass-through measurements are dominated by normal polarity directions, even in intervals where the discrete samples yield reverse-polarity directions. We interpret this as evidence for remagnetization of the rind of the core during drilling. Below 900 mbsf, only normal-polarity inclinations are observed in the discrete samples. Progressive AF de- 

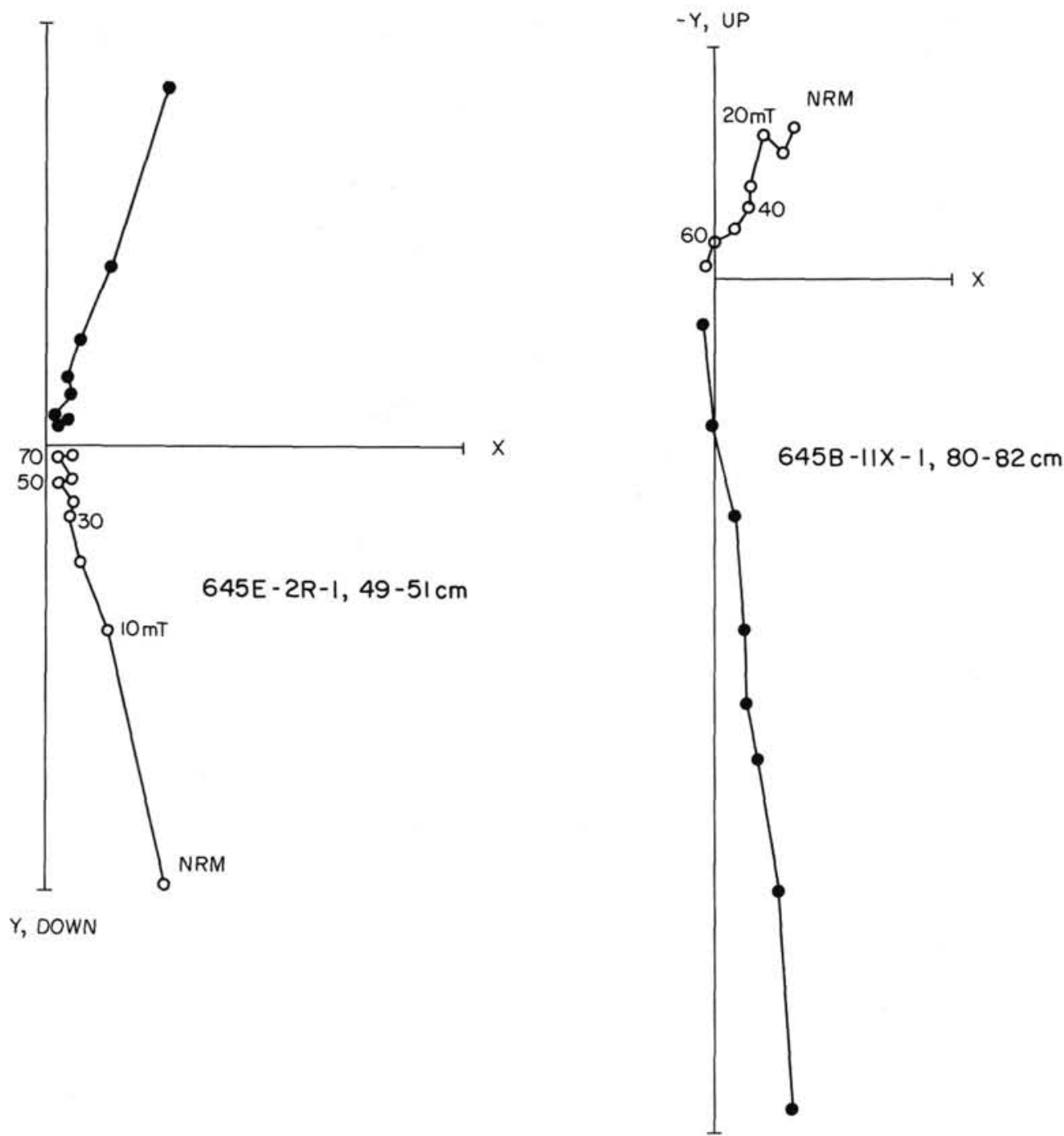

Figure 1. Results of progressive AF demagnetization of normal- and reverse-polarity samples from Site 645 plotted as vector end-point diagrams. Solid symbols represent projection onto the horizontal plane; open symbols represent projection onto the vertical plane. Samples were demagnetized at 10 -mT increments up to peak fields of $80 \mathrm{mT}$. Intensities have been normalized to natural remanent magnetism values.

magnetization of samples from this interval define single-component magnetizations having much lower median destructive fields ( 5 to $10 \mathrm{mT}$ ) than samples from higher in the section. The change in the median destructive field may indicate a change in the magnetic carriers in the sediments that made it more likely for these sediments to be remagnetized. Because of the frequency of polarity reversals in the early to middle Miocene and the poor biostratigraphic control, the observed polarity sequence cannot be correlated with the geomagnetic polarity time scale.

\section{Site 646}

Two holes were drilled at Site 646 in the southeastern Labrador Sea $\left(58^{\circ} 12.56^{\prime} \mathrm{N}, 48^{\circ} 22.15^{\prime} \mathrm{W}\right)$. Hole $646 \mathrm{~A}$ was cored with the APC to a total depth of $103.5 \mathrm{mbsf}$, and Hole $646 \mathrm{~B}$ was cored with the APC and XCB to a total depth of 766.7 mbsf. The sediments recovered at this site are silty clays and clayey silts of late Miocene to Holocene age. Although the sediments exhibit strong magnetizations (up to $200 \mathrm{~mA} / \mathrm{m}$ ), magnetostratigraphic study of these sediments is limited by poor recovery $(56 \%)$ in the deep parts of Hole 646B.

Progressive AF demagnetization of samples yielding both normal- and reverse-polarity magnetizations isolated univecto- rial magnetizations after treatment at 5 to $10 \mathrm{mT}$ (Fig. 5). This behavior is observed throughout the section, although samples from deep within Hole 646B exhibit a consistently downward component that was removed by treatment at peak fields of $10 \mathrm{mT}$.

Because the sediment cored at this site was so strongly magnetized, we were unable to measure archive core halves using the pass-through cryogenic magnetometer. Results of the discretesample measurments are shown in Figures 6 and 7. Inclination records from the APC intervals of Holes 646A and 646B are plotted in Figure 6. Polarity interpretations are based on the inclination data alone. We attempted to orient several cores (105$646 \mathrm{~B}-7 \mathrm{H},-8 \mathrm{H},-9 \mathrm{H},-10 \mathrm{H}, 12 \mathrm{H}$, and $-13 \mathrm{H}$ ) using the EastmanWhipstock multishot tool in an effort to provide a geographic reference frame for the intervals recording the Brunhes-Matuyama and the upper and lower Jaramillo polarity reversals. Unfortunately, this attempt was not successful because Cores 105 $646 \mathrm{~B}-7 \mathrm{H}$ and $-8 \mathrm{H}$ had no recovery, and problems with split liners reduced the usefulness of other oriented cores.

Visual correlation of lithologies between Holes 646A and 646B suggests an offset in sub-bottom depths between the two holes that is an artifact of coring. The inclination records shown 


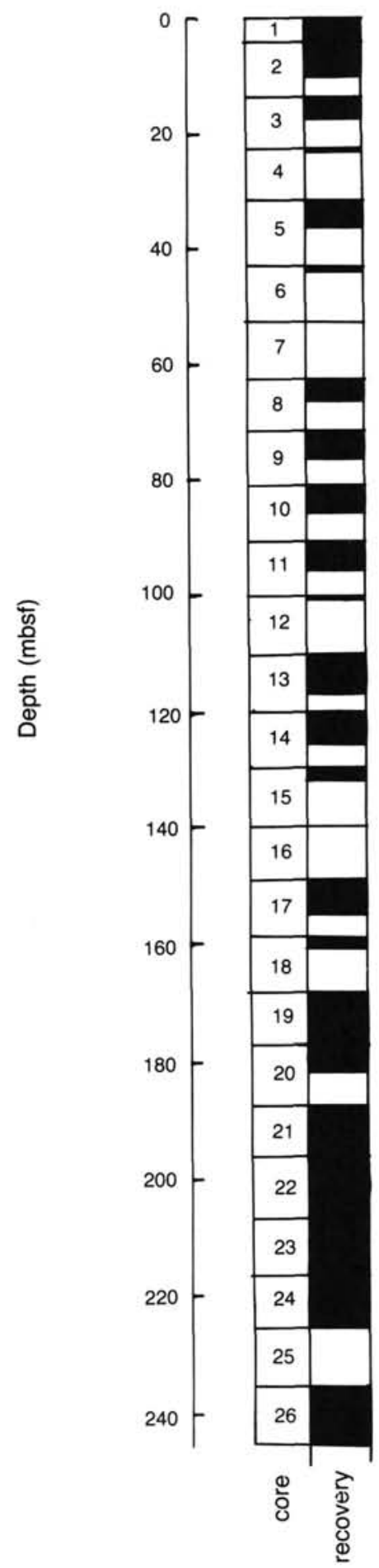

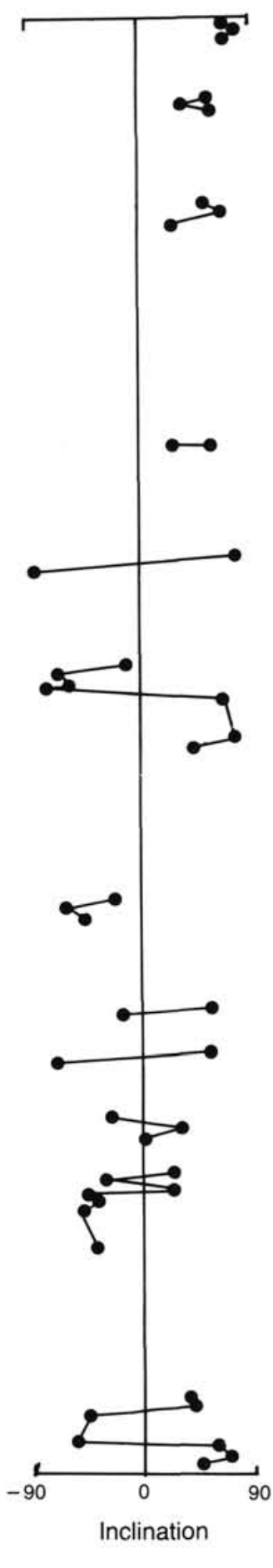

Hole 645B

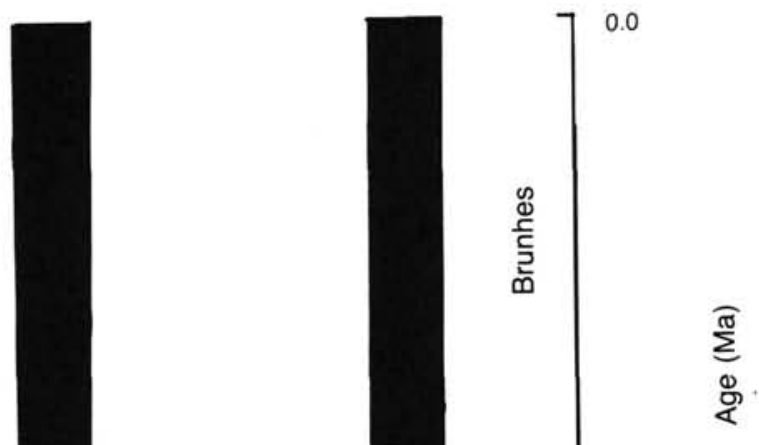

Figure 2. Inclination record obtained from Hole $645 \mathrm{~B}$ shown with polarity zonation and correlation with the geomagnetic polarity time scale. Recovery for the cores obtained from this hole also is shown.

in Figure 6 are plotted vs. uncorrected sub-bottom depths. Intervals of no recovery and sediment disturbance complicate the correlation of reversal boundaries between the two holes. The top of the Jaramillo Subchronozone may be the only polarity reversal recovered in both holes. It occurs $4 \mathrm{~m}$ shallower in Hole 646A than in Hole 646B, which supports the offset suggested by lithostratigraphic correlations (Srivastava, Arthur, et al., 1987).
The ages, bounding samples, and depths of these polarity reversals are given in Table 1.

The interval from Hole 646B cored with the XCB proved less well-suited for magnetostratigraphic study because of poorer recovery and greater drilling disturbance than was observed in the APC cores. Many cores contained drilling biscuits that had apparently rotated about a vertical axis within the core barrel dur- 

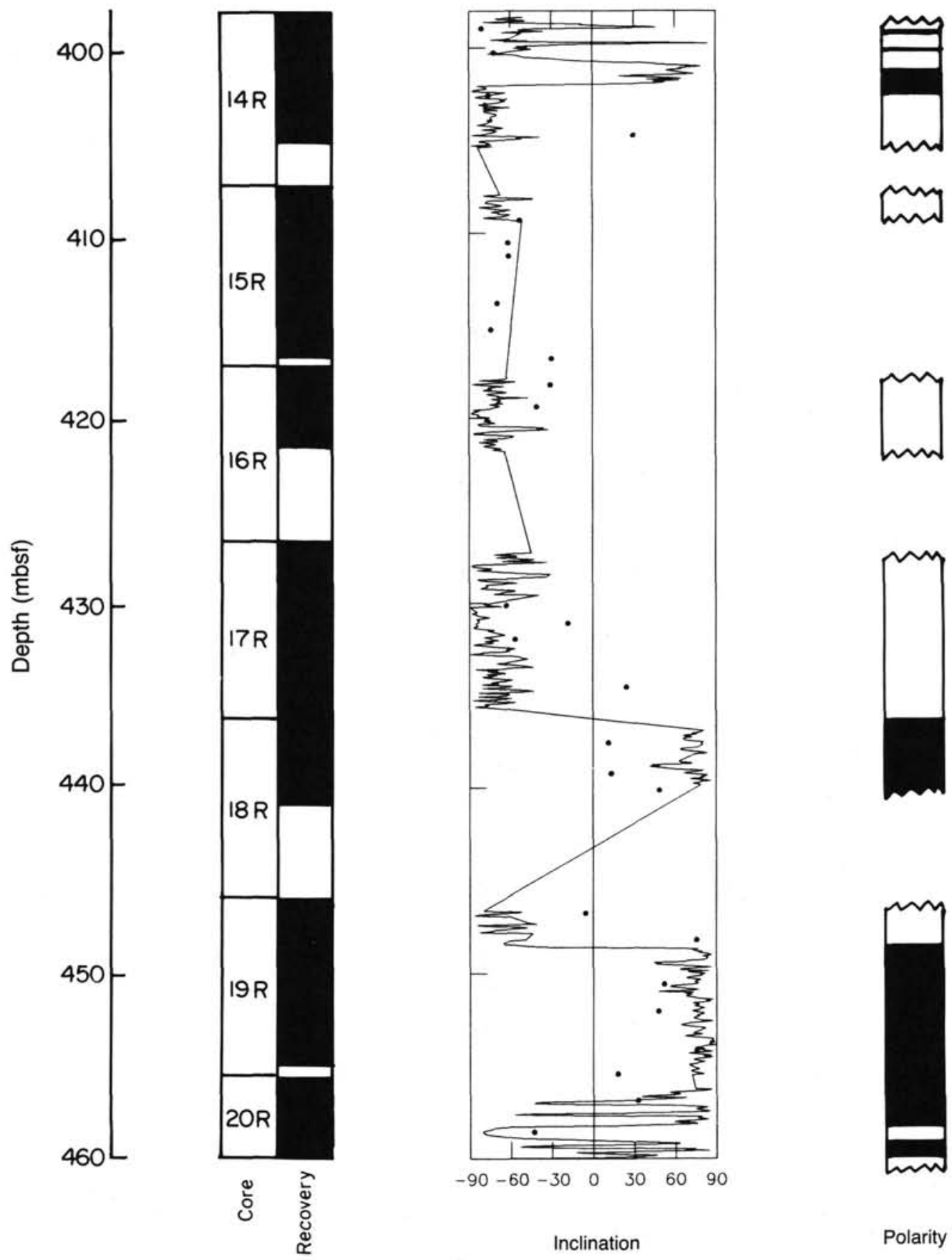

Figure 3. Inclination record obtained from Hole 645D using discrete-sample measurements and the shipboard pass-through cryogenic magnetometer. The polarity zonation is shown to the right. See text for discussion of correlation with the geomagnetic polarity time scale.

ing coring. However, careful sampling of these sediments provided the coarse polarity record shown in Figure 7 . The preferred correlation of the polarity reversals observed in Hole 646B with the geomagnetic polarity time scale is given in Table 1 . Because of the large gaps in the record, this correlation depends on the assumption of constant sedimentation rates between biostratigraphic tie points. The biostratigraphic results place the Pliocene-Pleistocene boundary at $144 \mathrm{mbsf}$, which is consistent with the correlation of the reverse-polarity interval from 52 to 190 mbsf with the Matuyama Chronozone. The early/late Pliocene boundary is placed at $312 \mathrm{mbsf}$, constraining the predominantly normal-polarity sediments between 190 and 290 mbsf to correlate with the Gauss Chronozone. The Miocene/Pliocene boundary falls within an interval of poor recovery at $486 \mathrm{mbsf}$, and we estimate that the base of the hole at $766.7 \mathrm{mbsf}$ is older than $8 \mathrm{Ma}$. These ages constrain the polarity sequence from 620 to 700 mbsf to correlate with Chronozone C4 to the top of Chronozone C4AN. We consider this correlation tenuous, given the incomplete polarity record.

\section{Site 647}

Site 647 was drilled in the southern Labrador Sea $\left(53^{\circ} 19.88^{\prime} \mathrm{N}\right.$, $\left.45^{\circ} 15.18^{\prime} \mathrm{W}\right)$. Hole $647 \mathrm{~A}$ was cored with the RCB to a total depth of 736 mbsf; Quaternary through lower Eocene silty- 


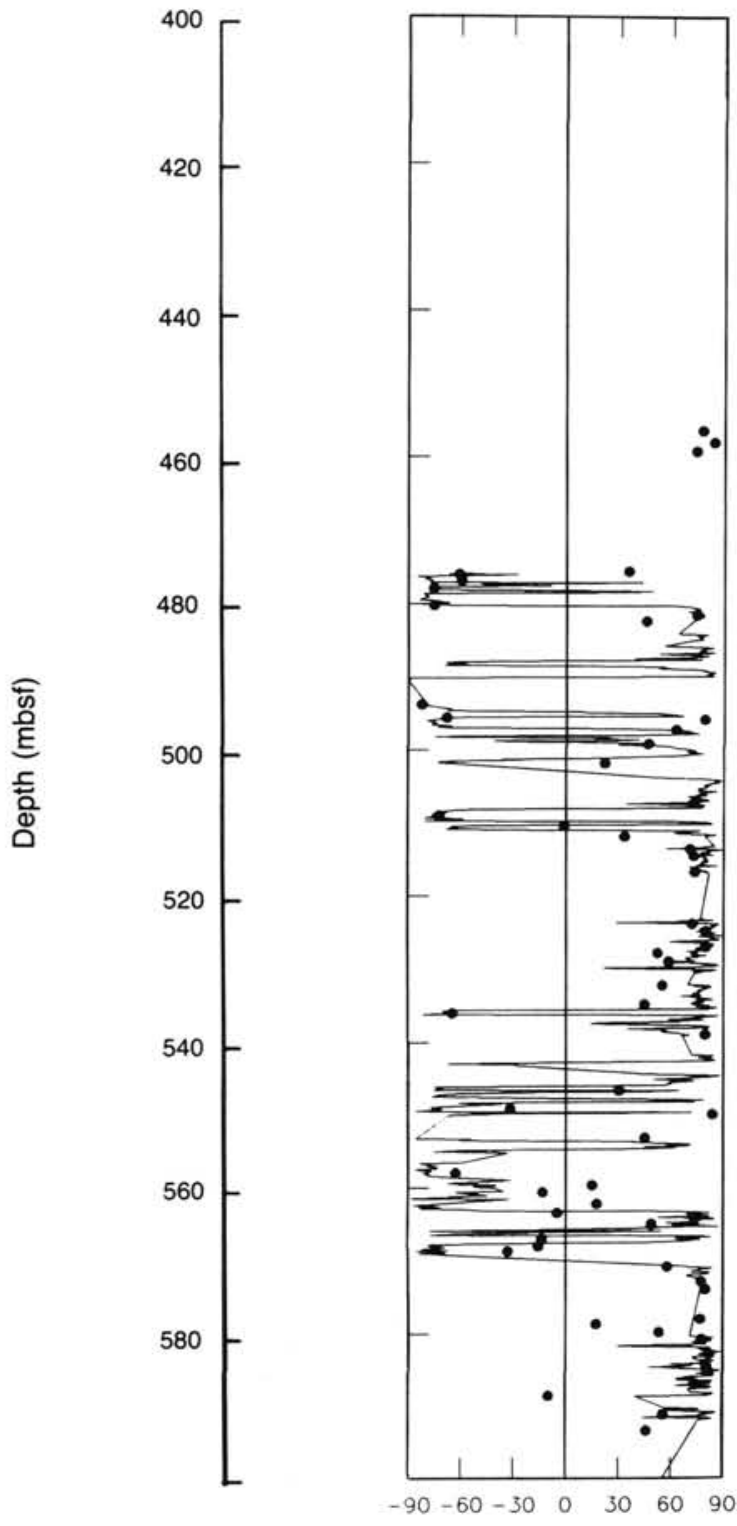

Inclination

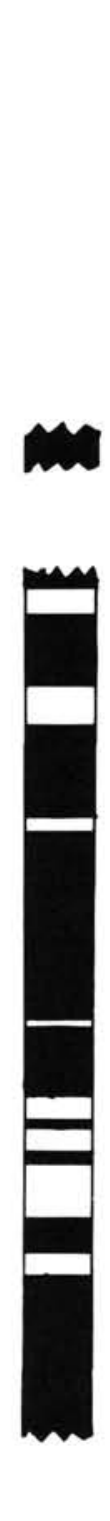

Polarity
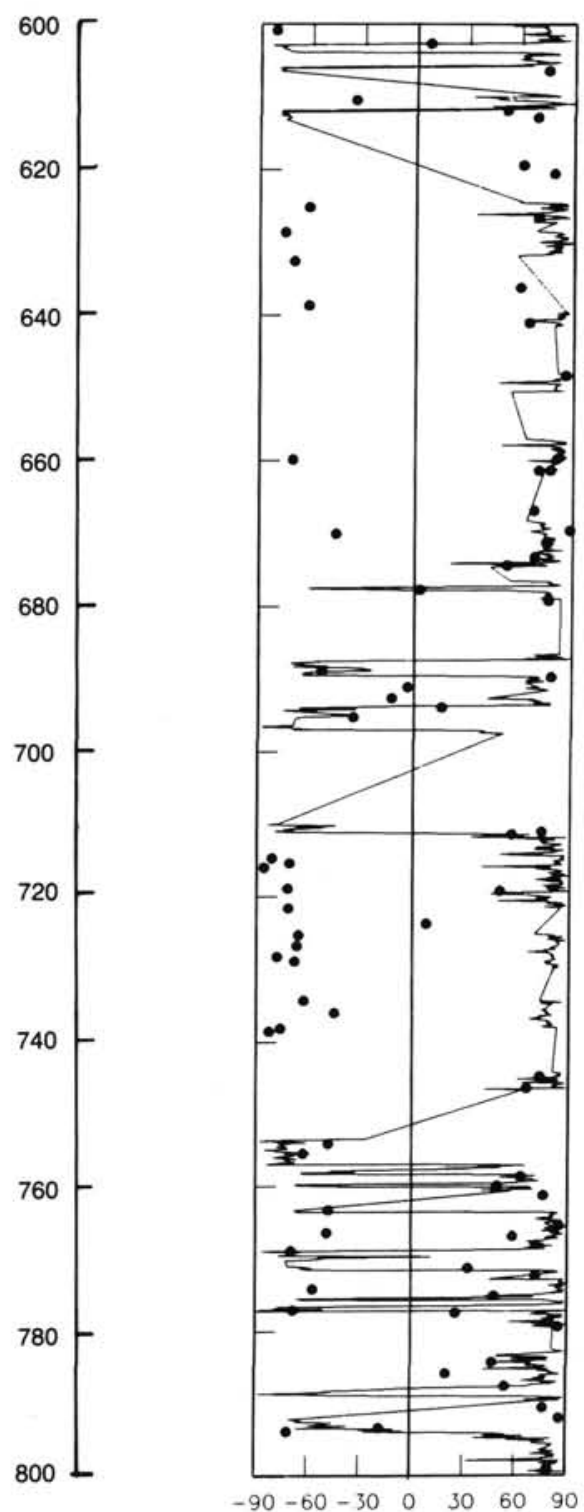

Inclination

Figure 4. Inclination records from rotary-cored Hole 645E obtained from both the pass-through cryogenic (solid line) and discrete samples (solid circles). Above $600 \mathrm{mbsf}$, the two sets of measurements are in good agreement. Below $600 \mathrm{mbsf}$, the pass-through record is affected strongly by a consistent normal-polarity overprint. Because of the difficulties resulting from the overprint and lack of biostratigraphic age control, correlation of the polarity zonation with the geomagnetic polarity time scale is considered tenuous.

clays, clayey muds, and clayey ooze to foraminifer- and nannofossil-bearing claystone were recovered. The APC was used to recover 11 cores from Hole 647B to a total depth of $103.3 \mathrm{mbsf}$.

Our magnetostratigraphic study of sediments cored at Site $647 \mathrm{~A}$ was limited by the availability of continuous sequences of undisturbed sediment. From the 11 piston cores taken at Hole $647 \mathrm{~B}$, a relatively undisturbed sequence of interbedded silty clays, clayey silts, and clayey muds was recovered. These sediments make up lithologic Unit I. Unlike drilling with the APC, drilling with the RCB in Hole 647A often disturbed unconsolidated sediments, limiting their use for paleomagnetic study. The sediments of lithologic Units III and IV, which are transitional from unconsolidated to indurated, were frequently broken up during rotary drilling, which produced "drilling biscuits," or coherent pieces of sediment that had rotated within a matrix of drilling slurry upon entering the core barrel. Only pieces with lengths exceeding the diameter of the core barrel could be sampled with any confidence that the block had not rotated about a horizontal axis, thereby compromising the orientation with respect to the vertical axis. In Hole 647A, coherent pieces meeting these criteria are scarce from 116 to $380 \mathrm{mbsf}$ and from 520 mbsf to the base of the hole. However, from 380 to $520 \mathrm{mbsf}$, a relatively continuous sequence of sediment suitable for paleomagnetic sampling was recovered.

Results of progressive AF demagnetization of samples from lithologic Unit I are illustrated in Figure 8. Treatment at peak fields of 5 to $10 \mathrm{mT}$ was successful at isolating univectorial magnetizations. The discrete samples from the upper $100 \mathrm{~m}$ of Holes 647A and 647B were treated at $10 \mathrm{mT}$.

Cores 105-647A-10R, $-11 \mathrm{R}$, and $-12 \mathrm{R}$ appear to be undisturbed and thus were measured using the shipboard pass-through cryogenic magnetometer. The pass-through inclination record 


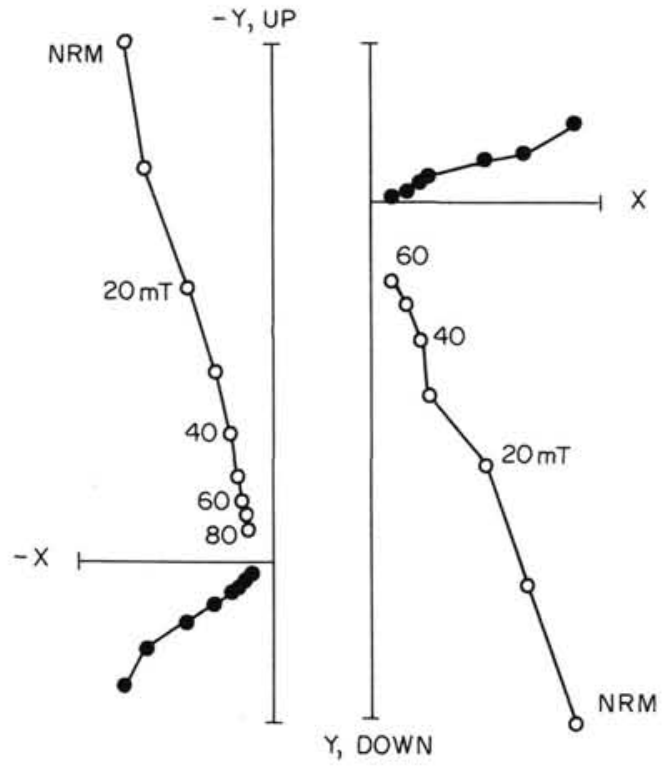

646B-IIH-5, 88-90 cm

$646 \mathrm{~B} \cdot 10 \mathrm{H} \cdot 4,113 \cdot 115 \mathrm{~cm}$

Figure 5. Results of progressive AF demagnetization of samples from Hole $646 \mathrm{~B}$ yielding normal- and reverse-polarity magnetizations. The results are plotted as vector end-point diagrams; solid circles represent projection onto the horizontal plane, open symbols represent projection onto the vertical plane. The intensities were normalized to the natural remanent magnetization values. The samples were demagnetized at increments of 5 to $10 \mathrm{mT}$, up to peak fields of $80 \mathrm{mT}$.

obtained after AF treatment at $5 \mathrm{mT}$ is shown in Figure 9, with the discrete-sample inclination record after treatment at $10 \mathrm{mT}$. The agreement between the two sets of data is remarkably good. Unfortunately, the uppermost sediments from Hole 647B proved too strongly magnetized to be measured using the cryogenic magnetometer. Therefore, only the discrete-sample inclination record is plotted in Figure 9. The Pliocene/Pleistocene boundary, as defined by the first appearance datum (FAD) of Globorotalia truncatulinoides and the last appearance datum (LAD) of Discoaster brouweri, is placed in Core 105-647A-8R, or at approximately $70 \mathrm{mbsf}$. Sediments from 70 to $116 \mathrm{mbsf}$ are late Pliocene in age. Based on these biostratigraphic constraints, the polarity sequences obtained from Holes 647A and 647B are correlated with the Brunhes and Matuyama chronozones. The top of the Gauss Chronozone occurs in Core 105-647A-12R. The ages and depths of the polarity intervals are given in Table 2.

The sediments comprising lithologic Units III and IV in Hole 647A appear to have undergone considerably more diagenesis than the unconsolidated, Pliocene-Pleistocene sediments of lithologic Unit I. The occurrence of alternating dusky red and green intervals in lithologic Unit IV (530.0-699 mbsf) suggests an increased importance of chemical diagenesis (Arthur et al., this volume; Bohrmann and Thiede, this volume) capable of affecting the remanent magnetization of these sediments. For this reason, each sample from Units III and IV was subjected to progressive demagnetization. Pilot samples from throughout the sequence were subjected to thermal or AF progressive demagnetization. Examples of the results of both AF and thermal demagnetization of samples from these lithologic units are shown in Figure 10, plotted as vector end-point diagrams. While AF demagnetization appears to isolate successfully characteristic magnetizations in sediments from Lithologic Unit III, thermal demagnetization is more successful for sediments from Unit IV. Characteristic directions were determined for each sample using principal-component analysis (Kirschvinck, 1980). The characteristic inclinations are plotted vs. sub-bottom depth in Figure 11.

The inclinations from the pass-through, cryogenic-magnetometer measurements after AF demagnetization at $9 \mathrm{mT}$ also are plotted. Only those core sections in which the fragments appeared to be in place were measured using the pass-through cryogenic magnetometer. The polarity zonation based on these results also is indicated in Figure 11.

Biostratigraphic data place Cores 105-647A-35R through -54R in the upper to middle Eocene. The Eocene/Oligocene boundary is defined by the occurrence of characteristic forms of calcareous nannofossils and planktonic and benthic foraminifers. The LAD of Discoaster barbadiensis, which marks the NP20/ NP21 zonal boundary, occurs in Sample 105-647A-30R-7, 48 $\mathrm{cm}$, while Section 105-647A-31 R, CC contains Globigerina linaperta, Turborotalia cerroazulensis s.l., and common agglutinated species, indicating a late Eocene age. The middle/upper Eocene boundary is defined by the FAD of Chiasmolithus oamaruensis. The $C$. oamaruensis datum (NP17/NP18) occurs in Core 105647A-46R.

Within these biostratigraphic constraints, the predominantly normal-polarity zone, extending from 400 to $452 \mathrm{mbsf}$, is correlated with Chronozones C17 and C18 (Berggren et al., 1985). The normal-polarity zone from 482 to 490 mbsf correlates with the normal-polarity interval in Chronozone C19. The depths and ages of reversals based on this correlation are given in Table 2.

This correlation places the nannofossil Zone NP16/Zone NP17 boundary within the lower portion of Chronozone C18N, which is consistent with Berggren et al.'s correlation (1985). However, the foraminifer zonal boundary, P14/P15, falls within Chronozone C18R, whereas Berggren et al.'s time scale (1985) places this boundary within Chronozone $C 17 \mathrm{~N}$. Because this zonal boundary is defined by a LAD, the true boundary may be higher than the shipboard results place it.

\section{DISCUSSION}

The APC-cored sediments recovered during Leg 105 provide a high sedimentation-rate record of upper Pliocene to Holocene polarity history at Sites 646 and 647 . The polarity sequences constrain the depth offset between the two piston-cored holes at Site 646, and the occurrence of short polarity intervals at both Sites 646 and 647 correlate well with similar intervals recorded in other piston-cored sediments from the North Atlantic.

Visual lithostratigraphic correlation of marker beds in Holes 646A and 646B suggests that at least a 3.5-m offset in depth exists between the two holes. The offset probably resulted from a double coring of the mud line in Hole 646A. Unfortunately, the top of the Jaramillo Subchronozone is the only reversal recorded in both Holes $646 \mathrm{~A}$ and $646 \mathrm{~B}$. This reversal occurs 4.4 $\pm 0.2 \mathrm{~m}$ deeper in Hole $646 \mathrm{~B}$ than in Hole 646A. This offset agrees well with the lithostratigraphic correlations (Srivastava, Arthur, et al., 1987). Using the estimates of the sub-bottom depths of core tops based on the visual correlations, the depth of the upper Jaramillo reversal in Hole 646A is $76.0 \pm 0.05$ mbsf, and the depth in Hole 646B is $76.7 \pm 0.1$ mbsf.

In addition to the Jaramillo and the Olduvai, additional short polarity intervals within the Matuyama are observed in sediments cored at Sites 646 and 647 . Although these polarity intervals are only defined by a few samples, they appear to correlate well with short polarity intervals observed in Matuyama sediments cored during Leg 94 in the North Atlantic (Clement and Robinson, 1986). A short normal-polarity interval can be seen $15 \mathrm{~m}$ below the top of the Jaramillo Subchronozone in Hole $646 \mathrm{~A}$ and $4.3 \mathrm{~m}$ below the base of the Jaramillo in Hole $647 \mathrm{~B}$. Using the sedimentation rates determined from the bestfit line through the age/depths of the Brunhes/Matuyama and Jaramillo reversals, age of the Cobb Mountain is $1.18 \mathrm{Ma}$ in 

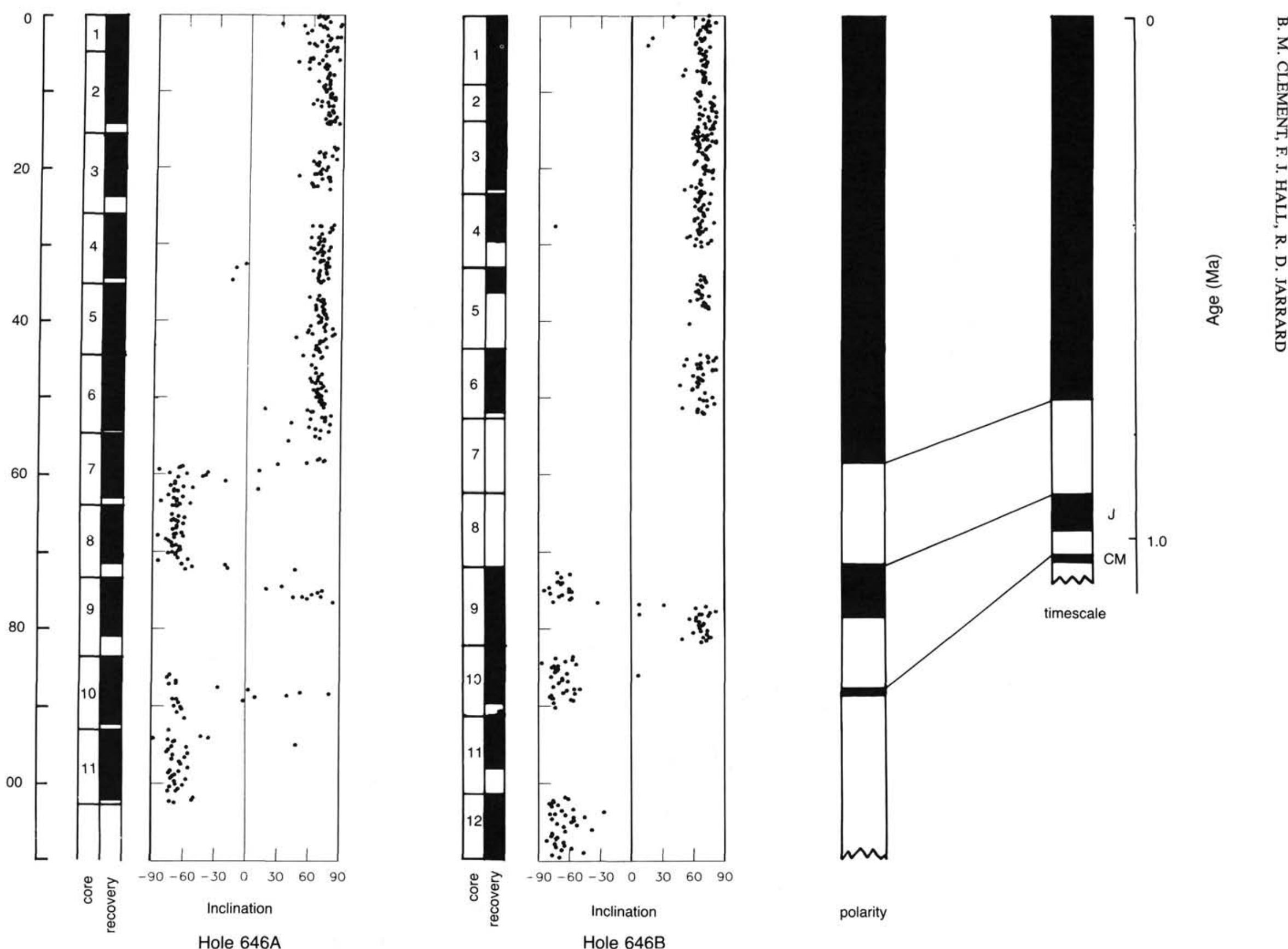

Figure 6. The inclination records obtained from the portions of Holes 646A and 646B cored with the APC. Correlation of the composite polarity zonation to the geomagnetic polarity time scale is indicated. Depths of the reversal boundaries in Holes 646A and 646B are given in Table 1. See text for discussion of depth offsets between holes. 

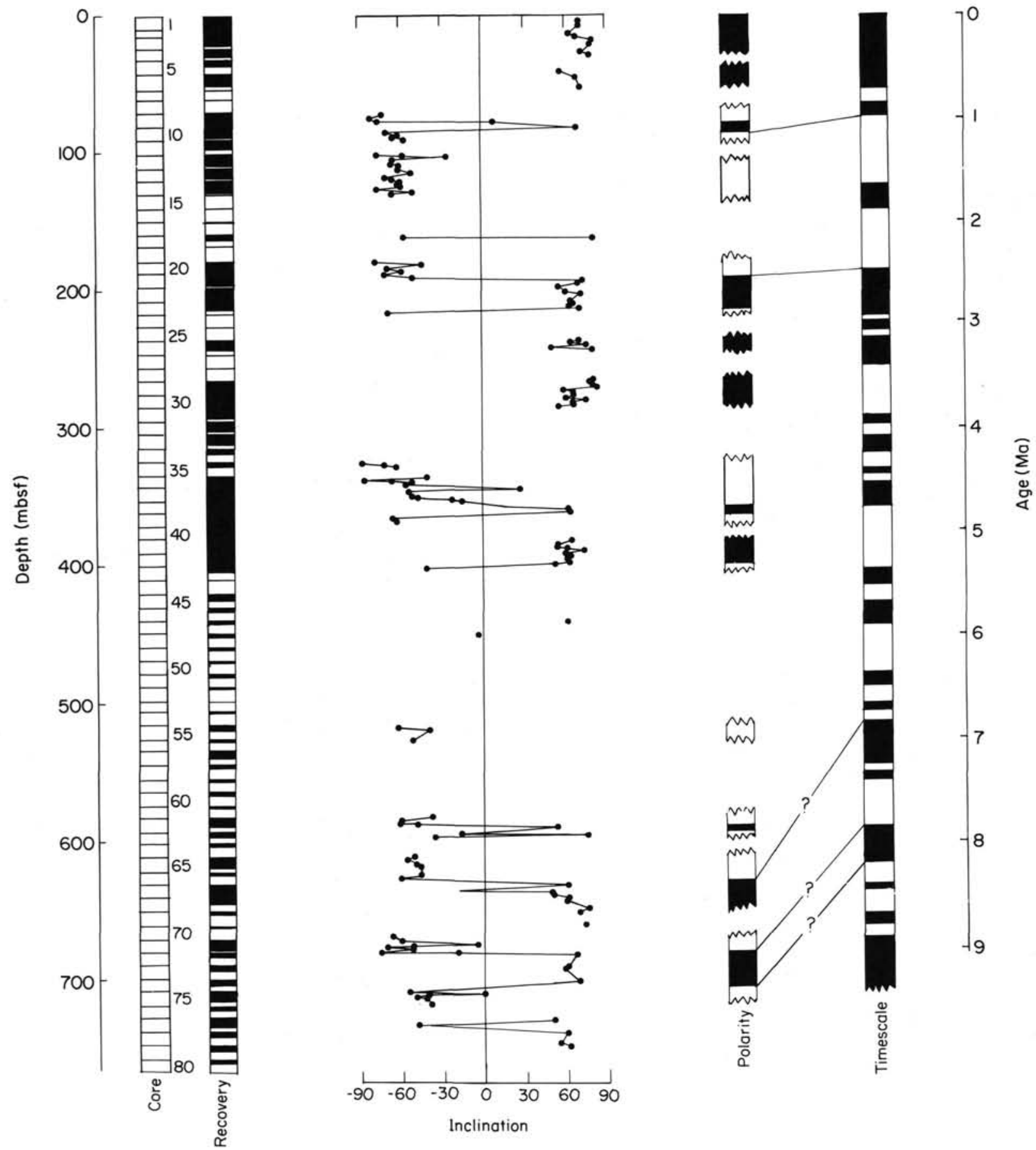

Figure 7. The inclination record obtained from Hole 646B cored with the APC and the XCB. Correlation of the polarity zonation to the geomagnetic polarity time scale is indicated.

Hole 646A and 1.10 $\mathrm{Ma}$ in Hole 647B. These ages agree well with the radiometric age of $1.12 \mathrm{Ma}$ reported by Mankinen et al. (1978). These ages also agree with the mean of estimates based on similar age interpolations at seven holes drilled during Leg 94.

In Hole 647B, two additional short polarity intervals are observed at depths corresponding to ages of 1.55 and $2.05 \mathrm{Ma}$. These intervals are correlated with the Gilsa and Reunion subchronozones (Clement and Kent, 1987; Mankinen and Dalrymple, 1979). Although these polarity subchronozones are not as well established as those of longer duration, it appears that in high sedimentation-rate sequences, the Cobb Mountain, Gilsa, and Reunion subchronozones may potentially provide additional stratigraphic control for Pliocene-Pleistocene studies.

\section{ACKNOWLEDGMENTS}

We thank two anonymous reviewers whose comments improved this manuscript. We also thank the Leg $105 \mathrm{Co}$-Chief Scientists, M. Arthur and S. Srivastava, and the Leg 105 Shipboard Party for their assistance during the cruise. Support for this work was provided by JOI USSAC Grant 76434 to B. Clement, JOI USSAC Grants 70760 and 76322 to F. Hall, and JOI USSAC Grant 76286 to R. Jarrard. 
Table 1. Ages and depths of reversal boundaries in Holes 646A and 646B.

\begin{tabular}{cccc}
\hline Reversal & Age & Bounding samples & Depth (mbsf) \\
\hline $\begin{array}{l}\text { Hole } 646 A \\
\begin{array}{l}\text { Brunhes/Matuyama } \\
\text { Jaramillo }\end{array}\end{array}$ & 0.73 & $7 \mathrm{H}-3,60 / 7 \mathrm{H}-3,87$ & $58.70 / 58.97$ \\
$\begin{array}{c}\text { Top } \\
\begin{array}{c}\text { Cobb Mountain } \\
\text { Top }\end{array}\end{array}$ & 0.91 & $8 \mathrm{H}-5,145 / 8 \mathrm{H}-6,4$ & $72.25 / 72.34$ \\
$\quad$ Bottom & 1.12 & $\begin{array}{l}10 \mathrm{H}-3,46 / 10 \mathrm{H}-3,80 \\
10 \mathrm{H}-4,3 / 10 \mathrm{H}-4,46\end{array}$ & $87.56 / 87.90$ \\
& & & $88.63 / 89.06$
\end{tabular}

Hole $646 B$

\begin{tabular}{|c|c|c|c|}
\hline $\begin{array}{l}\text { Brunhes/Matuyama } \\
\text { Jaramillo }\end{array}$ & 0.73 & $6 \mathrm{H}-6,120 / 8 \mathrm{H}-6,78$ & $52.10 / 73.86$ \\
\hline Top & 0.91 & $9 \mathrm{H}-3,120 / 9 \mathrm{H}-3,140$ & $76.60 / 76.80$ \\
\hline Bottom & 0.98 & $9 \mathrm{H}-7,30 / 10 \mathrm{H}-2,10$ & $81.70 / 83.60$ \\
\hline Matuyama/Gauss & 2.47 & $21 X-2,69 / 21 X-3,141$ & $190.40 / 192.60$ \\
\hline Gauss/Gilbert & 3.4 & $31 X-6,65 / 31 X-6,75$ & $292.85 / 292.95$ \\
\hline \multicolumn{4}{|l|}{ Chronozone C4 } \\
\hline Top N2 & 6.85 & $66 X-2,4 / 67 X-1,38$ & $625.24 / 632.18$ \\
\hline Bottom N2 & 7.28 & $70 X-1-70 / 71 X-1-114$ & $661.60 / 671.34$ \\
\hline \multicolumn{4}{|l|}{ Chronozone C4A } \\
\hline Top N1 & 7.90 & $72 X-1,36 / 72-2,81$ & $680.06 / 682.01$ \\
\hline Bottom N1 & 8.21 & $74 X-4,35 / 75 X-1,79$ & $702.85 / 708.39$ \\
\hline
\end{tabular}

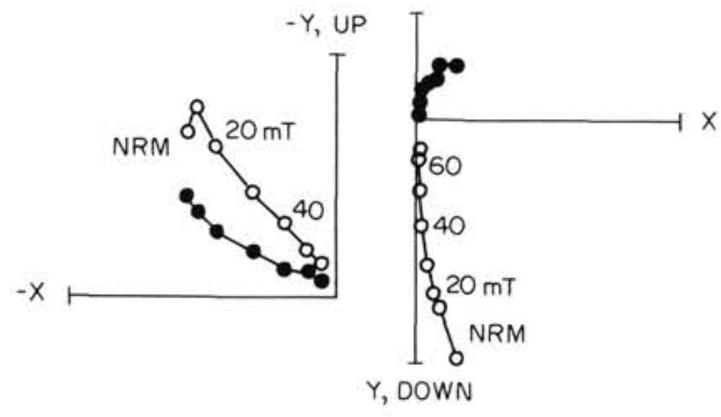

$6478-6 H-2,146-148 \mathrm{~cm}$

$647 \mathrm{~B}-4 \mathrm{H}-2,133-135 \mathrm{~cm}$

Figure 8. Results of progressive AF demagnetization of samples from Hole 647B yielding normal- and reverse-polarity magnetizations. Results are plotted as vector end-point diagrams; solid circles represent projection onto the horizontal plane, open symbols represent projection onto the vertical plane. Intensities were normalized to the natural remanent magnetization values. The samples were demagnetized at increments of 5 to $10 \mathrm{mT}$, up to peak fields of $70 \mathrm{mT}$.

\section{REFERENCES}

Berggren, W. A., Kent, D. V., Flynn, J. J., and Van Couvering, J. A., 1985. Cenozoic geochronology. Geol. Soc. Am. Bull., 96:1407-1418.

Clement, B. M., and Robinson, F., 1986. The magnetostratigraphy of Leg 94 sediments. In Ruddimnan, W. F., Kidd, R. B., Thomas, E., et al., Init. Repts. DSDP, 94: Washington (U.S. Govt. Printing Office), 635-650.

Clement, B. M., and Kent, D. V., 1987. Short polarity intervals within the Matuyama: transitional field records from hydraulic piston-cored sediment from the North Atlantic. Earth Planet. Sci. Lett., 81:253264.

Cox, A. V., 1982. Magnetostratigraphic time scale. In Harland, W. B., et al. (Eds.), A Geologic Time Scale: Cambridge (Cambridge Univ. Press), 63-64.

Gradstein, F. M., and Srivastava, S. P., 1980. Aspects of Cenozoic stratigraphy and paleoceanography of the Labrador Sea and Baffin Bay. Palaeogeogr., Palaeoclimatol., Palaeoecol., 30:261-295.

Heirtzler, J. R., Dickson, G. O., Herron, E. M., Pitman, W. C., III, and LePichon, X., 1968. Marine magnetic anomalies, geomagnetic field reversals, and motions of the ocean floor and continents. $J$. Geophys. Res., 73:2119-2136.

Kirschvink, J. L., 1980. The least-squares line and plane and the analysis of paleomagnetic data. Geophys. J. Roy. Astr. Soc., 62:699-718.

LaBrecque, J. L., Kent, D. V., and Cande, S. C., 1977. Revised magnetic polarity time scale for Late Cretaceous and Cenozoic time. Geology, 5:330-335.

LaBrecque, J. L., and Shipboard Scientific Party, DSDP Leg 73, 1983. Contributions to Paleogene stratigraphy in nomenclature, chronology, and sedimentation rates. Palaeogeogr., Palaeoclimatol., Palaeoecol., 42:91-125.

Mankinen, E. A., and Dalrymple, G. B., 1979. Revised geomagnetic polarity time scale for the interval, 0-5 m.y.B.P. J. Geophys. Res., 84:615-626.

Mankinen, E. A., Donnelly, J. M., and Gromme, C. S., 1978. Geomagnetic polarity event recorded at 1.1 m.y.B.P. on Cobb Mountain, Clear Lake volcanic field, California. Geology, 6:653-656.

Miller, K.G., Aubry, M.-P., Khan, M. J., Melillo, A. J., Kent, D. V. and Berggren, W. A., 1985. Oligocene to Miocene bio-magneto and isotopic stratigraphy of the western North Atlantic. Geology, 13: 257-561.

Ness, G., Levi, S., and Couch, R., 1980. Marine magnetic anomaly time scales for the Cenozoic and Late Cretaceous: a precis, critique, and synthesis. Rev. Geophys. Space Phys., 18:753-770.

Srivastava, S. P., Arthur, M., et al., 1987. Proc. ODP, Init. Repts., 105: College Station, TX (Ocean Drilling Program).

Tauxe, L., Butler, R., and Herguera, J. C., 1987. Magnetostratigraphy: in pursuit of missing links. Rev. Geophy. Space Phys., 25:939-950.

Zijderveld, J.D.A., 1967. AC demagnetization of rocks: analysis of results. In Colklinson, D. W., Creer, K. M., and Runcorn, S. K. (Eds.), Methods in Paleomagnetism: New York (Elsevier), 254-286.

Date of initial receipt: 22 January 1988

Date of acceptance: 29 September 1988

Ms 105B:147 

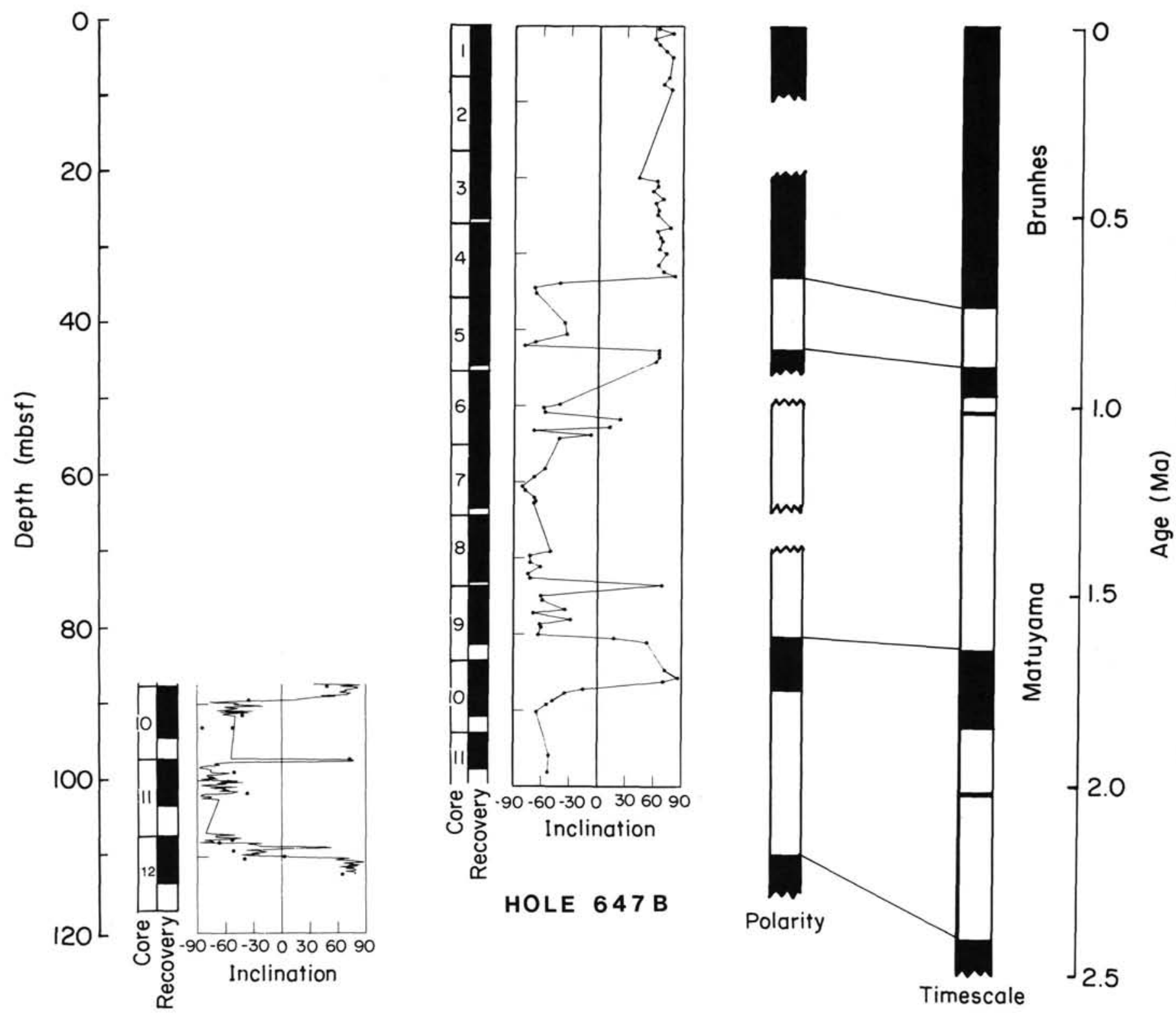

\section{HOLE $647 \mathrm{~A}$}

Figure 9. Inclination records obtained from lithologic Unit I in RCB-cored Hole 647A and APC-cored Hole 647B. Results from both pass-through and discrete-sample measurements are plotted for Hole 647A. Correlation of the polarity zonation with the geomagnetic polarity time scale is indicated. 
B. M. CLEMENT, F. J. HALL, R. D. JARRARD

Table 2. Ages and depths of reversal boundaries in Holes 647A and 647B.

\begin{tabular}{|c|c|c|c|}
\hline Reversal & Age & Bounding samples & Depth (mbsf) \\
\hline \multicolumn{4}{|l|}{ Hole $647 A$} \\
\hline \multicolumn{4}{|l|}{ Olduvai } \\
\hline Bottom & 1.88 & $10 \mathrm{R}-2,65 / 10 \mathrm{R}-2,75$ & $89.44 / 89.54$ \\
\hline Reunion & 2.10 & $11 \mathrm{R}-1,25 / 11-1,55$ & $97.25 / 97.55$ \\
\hline Matuyama/Gauss & 2.47 & $12 \mathrm{R}-3,15 / 12 \mathrm{R}-3,25$ & $109.84 / 109.94$ \\
\hline \multicolumn{4}{|l|}{ Chronozone $\mathrm{C} 18$} \\
\hline Bottom & 42.73 & $47 \mathrm{R}-5,148 / 48 \mathrm{R}-1,5$ & $450.75 / 453.25$ \\
\hline \multicolumn{4}{|l|}{ Chronozone C19 } \\
\hline Top N1 & 43.60 & $50 \mathrm{R}-6,145 / 51 \mathrm{R}-1,5$ & $481.45 / 482.15$ \\
\hline Bottom N1 & 44.06 & $51 \mathrm{R}-6,55 / 51 \mathrm{R}-6,65$ & $490.15 / 490.25$ \\
\hline \multicolumn{4}{|l|}{ Hole $647 B$} \\
\hline Brunhes/Matuyama & \multirow{2}{*}{\multicolumn{3}{|c|}{ Jaramillo }} \\
\hline $\begin{array}{c}\text { Jaramillo } \\
\text { Top }\end{array}$ & 0.91 & $5 \mathrm{H}-5,26 / 5 \mathrm{H}-5,88$ & \\
\hline Bottom & 0.98 & $5 \mathrm{H}-6,88 / 6 \mathrm{H}-3,130$ & $44.18 / 49.80$ \\
\hline \multicolumn{4}{|l|}{ Olduvai } \\
\hline Top & 1.66 & $9 \mathrm{H}-4,130 / 9 \mathrm{H}-5,25$ & $80.10 / 80.55$ \\
\hline Bottom & 1.88 & $10 \mathrm{H}-2,80 / 10 \mathrm{H}-3,32$ & $86.20 / 87.22$ \\
\hline
\end{tabular}
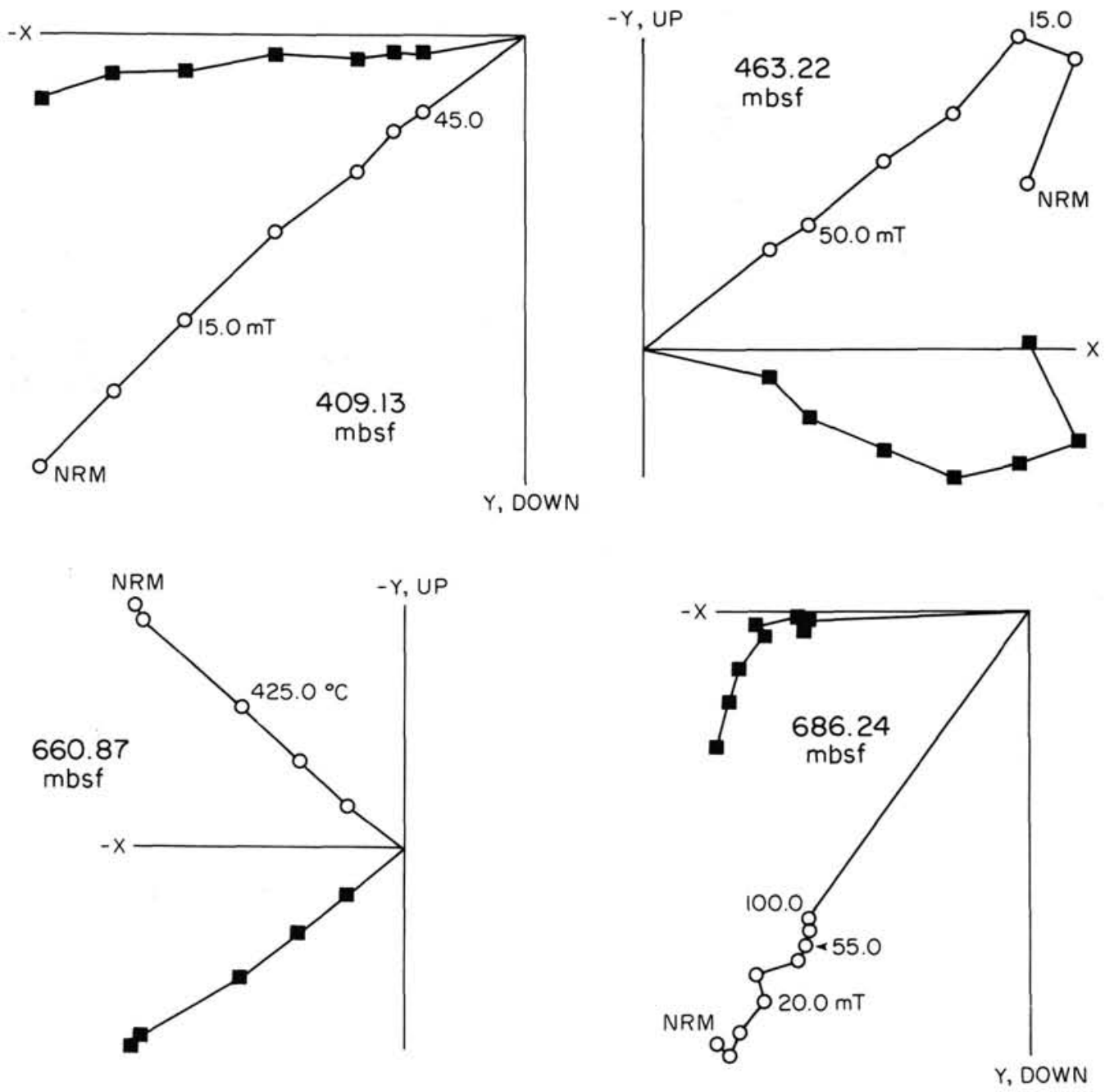

Figure 10. Vector end-point diagrams showing the response of samples from the deeper intervals of Hole 647A to $\mathrm{AF}$ and thermal demagnetization. Samples above $600 \mathrm{mbsf}$ responded well to AF demagnetization, while those from deeper in the hole responded better to thermal demagnetization. 

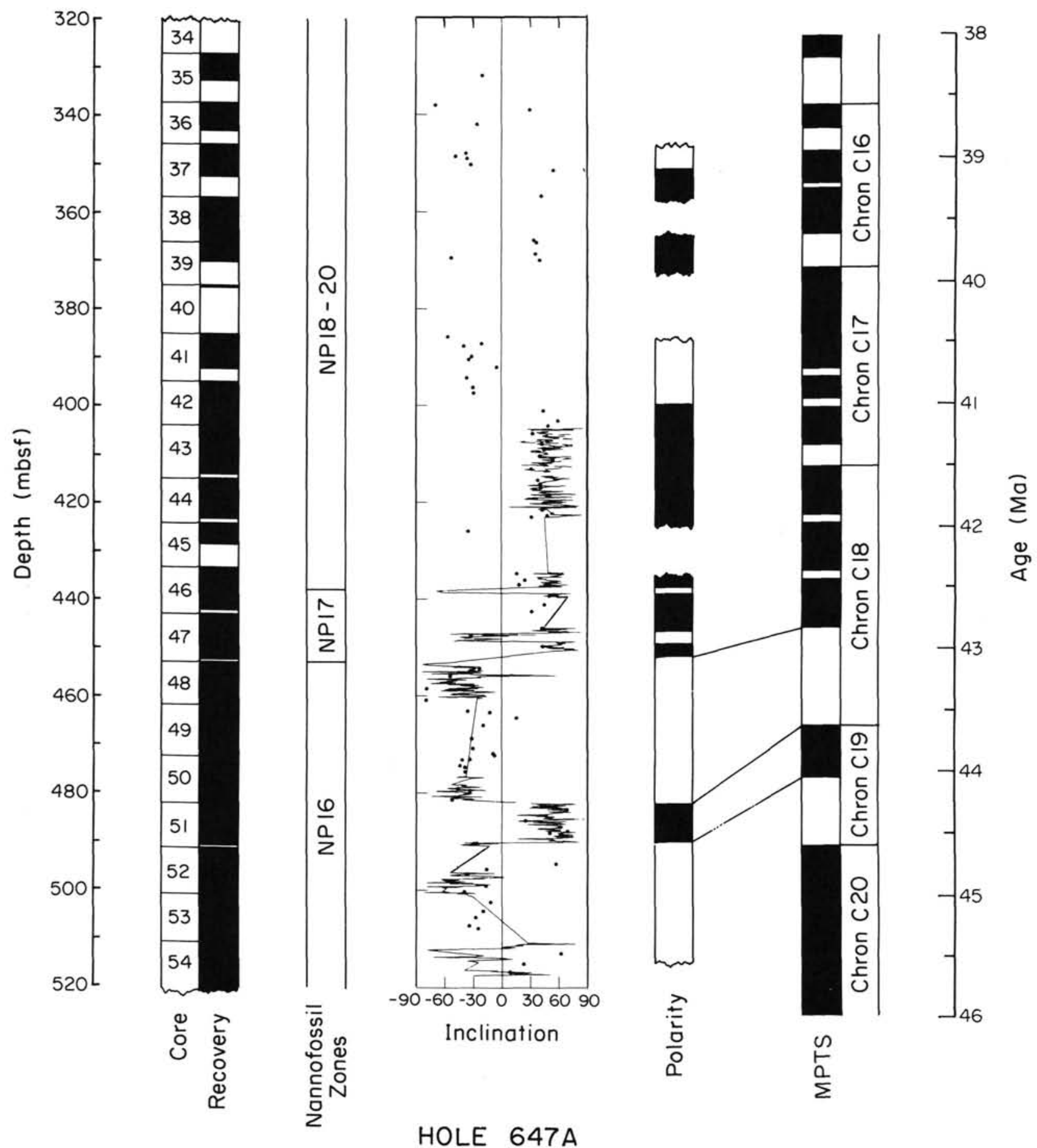

Figure 11. The pass-through inclination record and the characteristic inclinations obtained from Hole 647A. Also shown is the core recovery, the nannofossil zonation, and the correlation of the polarity zonation with the geomagnetic polarity time scale. 